\title{
Trend Analyses of Critical Values Obtained for Sender Node Energy Savings Achievable in Ubicomp MANETs Using Location-Aware Transmission.
}

\author{
M. Kaleem GALAMALI, Assoc. Prof Nawaz MOHAMUDALLY
}

\begin{abstract}
MANET transmission strategies coupled with location-awareness is welcome in ubicomp [1-45] and hence remain good topics of research. The success of these strategies depend heavily on the correct protocol designs being adopted. Current research attempts assume present methods for protocol design as heuristic in nature [83] and hence not so suitable for "correct the first time implementations". Optimisation methods for tuning parameters in middleware services and applications [84] is needed and suitability of traditional layered architecture in networking is also questioned [85] in terms of QoS and node densities. A further aim in this direction is to achieve realism in design and evaluation of wireless routing protocols [86]. This can be enhanced towards predictability in ubicomp. Achieving realism is a very long process since it will involve realism in each aspect concerned with ubicomp. Such an aspect was studied in a previous research [14] to assess the trend of energy savings achievable by sender node (SES) in LocationAware MANET Transmission, followed by the study of trends for each SES parameter of equations [30].
\end{abstract}

To enhance the components towards realism in knowledge of these trends, in this paper, the next set of questions to be investigated is put forward as: "What are the observable critical values in SES trends? What are the trends of variation observable within each critical value for metric SES over varying node densities?"

Such knowledge will assist designers in producing more realistic ubicomp scenarios over which new ubicomp features and protocols can be tested more realistically. This work follows-up from previous work [1-45].

Key terms: Ubicomp- Ubiquitous Computing, MAUCMobile and Ubiquitous Computing, ES- Energy Savings, SES- Sender ES, MANET- Mobile Adhoc Network, CBRConstant Bit Rate, CV- Critical Value.

M. Kaleem GALAMALI,

University of Technology Mauritius (student) Mauritius

Assoc. Prof Nawaz Mohamudally University of Technology Mauritius, Mauritius

\section{Introduction}

Many factors [2] are known to affect energy consumption in MAUC. Type of transmission and node density also remain pertinent factors. In a previous research [14], an effort was made to find a particular trend/model which depicts energy savings that can be reached by senders in MAUC (SES) to rate the effectiveness of location-aware MANET transmission strategies compared to the theoretical/empirical models derived in simulations. The model put forward for metric SES was the exponential model of form:

$$
F(x)=a * \exp (b *(x-c))
$$

The study which followed [30] was mathematical modelling of the trends of the three parameters of equation obtained. Mention was also made in that same paper [30] that such knowledge will help designers to better understand evolution and predictability of ubicomp environments. To help in such aspect, one feature that can be produced is a platform of realistic simulation scenarios over which testing of newly developed components, including communication protocols, can be carried out.

The next probing that is required for the metric SES is identifying certain key critical values obtained during experimentations and formulating the corresponding trend of variations over varying node densities for each critical value. Seven such critical values were obtained.

The key contribution of this paper is the establishment of the trend of variation covering node numbers 7 until 56 , for each of the seven critical values observed for metric SES introduced in previous papers [14, 30]. Availability of such data will aid ubicomp designers to better understand the evolution and predictability of ubicomp environment and formulate more realistic simulation scenarios over which new communication protocols designed could be tested. The rest of this paper is organised as follows: section 2- SES Critical Values, section 3- Critical Values Trend AnalysesMetric SES, section 4- Conclusion and References.

\section{SES Critical Values.}

\subsection{Critical Values Identified.}

Seven critical values have been identified as follows: Column headings are: $\mathrm{C} 1 \rightarrow$ SES Critical Value, $\mathrm{C} 2 \rightarrow$ Meaning of SES Critical Value, C3 $\rightarrow$ Corresponding figure number for the SES Critical Value. 
Proc. of the Seventh International Conference On Advances in Computing, Electronics and Electrical Technology - CEET 2017. Copyright (C) Institute of Research Engineers and Doctors. All rights reserved.

ISBN: 978-1-63248-126-9 doi: 10.15224/ 978-1-63248-126-9-19

\begin{tabular}{|c|l|c|}
\hline C1 & \multicolumn{1}{|c|}{ C2 } & C3 \\
\hline 1 & Smallest SES value obtained. & 1 \\
\hline 2 & $\begin{array}{l}\text { \%CBR at highest value of SES } \\
\text { obtained. }\end{array}$ & 2 \\
\hline 3 & Modal value of SES. & 3 \\
\hline 4 & \%CBR at modal value of SES. & 4 \\
\hline 5 & \%CBR with SES value below modal & 5 \\
\hline 6 & \%alue. & 6 \\
\hline 7 & MCBR with SES value greater than & 6 \\
\hline
\end{tabular}

Table 1: SES Critical Values

\subsection{Experimental Critical Values Obtained.}

The values obtained in experiments are summarised below. Values have been rounded to a maximum of 9 decimal places. Column heading NN $\rightarrow$ Node Number.

\begin{tabular}{|r|r|c|c|c|}
\hline NN & CV1 & CV2 & CV3 & CV4 \\
\hline 7 & 2 & 0.079365079 & 94 & 9.603174603 \\
\hline 8 & 2 & 13.482967208 & 100 & 13.482967208 \\
\hline 9 & 2 & 13.571428571 & 100 & 13.571428571 \\
\hline 10 & 3 & 12.063492063 & 97 & 12.476190476 \\
\hline 11 & 3 & 12.380952381 & 97 & 14.031746032 \\
\hline 12 & 3 & 12.496025437 & 97 & 14.642289348 \\
\hline 13 & 3 & 12.571428571 & 98 & 15.603174603 \\
\hline 14 & 3 & 12.888888889 & 98 & 16.888888889 \\
\hline 15 & 3 & 13.047619048 & 98 & 18.730158730 \\
\hline 16 & 3 & 13.206349206 & 98 & 19.857142857 \\
\hline 17 & 4 & 13.365079365 & 98 & 21.142857143 \\
\hline 18 & 4 & 13.761904762 & 98 & 21.428571429 \\
\hline 19 & 4 & 14.079365079 & 98 & 19.984126984 \\
\hline 20 & 4 & 14.158730159 & 98 & 20.063492063 \\
\hline 21 & 4 & 13.539682540 & 98 & 21.380952381 \\
\hline 22 & 4 & 13.984126984 & 99 & 22.777777778 \\
\hline 23 & 4 & 14.349206349 & 99 & 24.285714286 \\
\hline 24 & 4 & 14.825396825 & 99 & 25.206349206 \\
\hline 25 & 4 & 14.984126984 & 99 & 26.634920635 \\
\hline 26 & 4 & 14.507936508 & 99 & 28.174603175 \\
\hline 27 & 4 & 14.904761905 & 99 & 28.968253968 \\
\hline 28 & 4 & 15.063492063 & 99 & 30.619047619 \\
\hline 29 & 4 & 15.222222222 & 99 & 32.253968254 \\
\hline 30 & 4 & 15.507936508 & 99 & 33.095238095 \\
\hline 31 & 4 & 16.174603175 & 99 & 34.396825397 \\
\hline 32 & 4 & 16.730158730 & 99 & 34.984126984 \\
\hline 33 & 4 & 17.000000000 & 99 & 36.158730159 \\
\hline 34 & 4 & 17.730158730 & 99 & 36.301587302 \\
\hline 35 & 4 & 18.095238095 & 99 & 37.142857143 \\
\hline 36 & 4 & 18.253968254 & 99 & 37.904761905 \\
\hline 37 & 4 & 18.050484204 & 99 & 38.307667884 \\
\hline 38 & 4 & 18.285714286 & 99 & 39.079365079 \\
\hline 39 & 4 & 18.682539683 & 99 & 40.253968254 \\
\hline 40 & 4 & 19.000000000 & 99 & 41.158730159 \\
\hline 41 & 4 & 19.4444444444 & 99 & 41.809523810 \\
\hline 42 & 4 & 20.126984127 & 99 & 42.317460317 \\
\hline 43 & 4 & 20.269841270 & 99 & 43.000000000 \\
\hline 44 & 4 & 20.822744600 & 99 & 43.694409149 \\
\hline & & & \\
\hline 19 & &
\end{tabular}

\begin{tabular}{|r|r:|l|l|l|}
\hline 45 & 4 & 21.412698413 & 99 & 44.031746032 \\
\hline 46 & 4 & 21.777777778 & 99 & 44.412698413 \\
\hline 47 & 4 & 22.333333333 & 99 & 44.126984127 \\
\hline 48 & 4 & 22.825396825 & 99 & 44.380952381 \\
\hline 49 & 4 & 23.269841270 & 99 & 44.619047619 \\
\hline 50 & 4 & 24.142857143 & 99 & 44.825396825 \\
\hline 51 & 4 & 24.555555556 & 99 & 45.063492063 \\
\hline 52 & 4 & 24.841269841 & 99 & 45.158730159 \\
\hline 53 & 4 & 25.269841270 & 99 & 45.190476190 \\
\hline 54 & 4 & 25.825396825 & 99 & 45.269841270 \\
\hline 55 & 4 & 26.730158730 & 99 & 44.825396825 \\
\hline 56 & 4 & 27.047619048 & 99 & 45.222222222 \\
\hline
\end{tabular}

Table 2a: Experimental Critical Values Obtained(1)

\begin{tabular}{|c|c|c|c|}
\hline NN & CV5 & CV6 & CV7 \\
\hline 7 & 61.619047619 & 28.777777778 & 73 \\
\hline 8 & 86.517032792 & 0.000000000 & 73 \\
\hline 9 & 86.428571429 & 0.000000000 & 77 \\
\hline 10 & 60.666666667 & 26.857142857 & 85 \\
\hline 11 & 56.126984127 & 29.841269841 & 86 \\
\hline 12 & 52.480127186 & 32.877583466 & 87 \\
\hline 13 & 63.968253968 & 20.428571429 & 88 \\
\hline 14 & 60.936507937 & 22.174603175 & 88 \\
\hline 15 & 57.476190476 & 23.793650794 & 89 \\
\hline 16 & 54.857142857 & 25.285714286 & 90 \\
\hline 17 & 52.190476190 & 26.666666667 & 91 \\
\hline 18 & 50.111111111 & 28.460317460 & 91 \\
\hline 19 & 48.317460317 & 31.698412698 & 92 \\
\hline 20 & 46.476190476 & 33.460317460 & 92 \\
\hline 21 & 43.920634921 & 412698 & 92 \\
\hline 22 & & & \\
\hline 23 & 61.365079365 & 14.349206349 & 92 \\
\hline 24 & 59.968253968 & 14.825396825 & 92 \\
\hline 25 & 58.380952381 & 14.984126984 & 93 \\
\hline 26 & 57.317460317 & 14.507936508 & 93 \\
\hline 27 & & & \\
\hline 28 & 54.317460317 & 15.063492063 & 94 \\
\hline 29 & 52.523809524 & 15.222222222 & 94 \\
\hline 30 & 51.396825397 & 15.507936508 & \\
\hline 31 & 49.428571 & 16.174603175 & 94 \\
\hline 32 & 48.285714286 & 16.730158730 & \\
\hline 33 & 46.841269841 & 17.000000000 & 94 \\
\hline 34 & 45.968253968 & 17.730158730 & 95 \\
\hline 35 & 44.761904762 & 18.095238095 & 95 \\
\hline 36 & 43.841269841 & 18.253968254 & 95 \\
\hline 37 & 43.641847912 & 18.050484204 & 95 \\
\hline 38 & 42.634920635 & 18.285714286 & \\
\hline 39 & 41.063492063 & 18.682539683 & 95 \\
\hline 40 & 39.841269841 & 19.000000000 & 95 \\
\hline 41 & 38.746031746 & 19.444444444 & \\
\hline 42 & 37.555555556 & 20.126984127 & 95 \\
\hline 43 & 36.730158730 & 20.269841270 & 95 \\
\hline 44 & 35.482846252 & 20.822744600 & 95 \\
\hline 45 & 34.555555556 & 21.412698413 & 96 \\
\hline 46 & 33.809523810 & 21.777777778 & \\
\hline 47 & 33.539682540 & 22.333333333 & 96 \\
\hline 48 & 32.793650794 & 22.825396825 & 96 \\
\hline 49 & 32.111111111 & 23.269841270 & \\
\hline
\end{tabular}


Proc. of the Seventh International Conference On Advances in Computing, Electronics and Electrical Technology - CEET 2017. Copyright (C) Institute of Research Engineers and Doctors. All rights reserved.

ISBN: 978-1-63248-126-9 doi: 10.15224/ 978-1-63248-126-9-19

\begin{tabular}{|c|c|c|c|c|}
\hline 50 & 31.031746032 & 24.142857143 & 97 \\
\hline 51 & 30.380952381 & 24.555555556 & 97 \\
\hline 52 & 30.000000000 & 24.841269841 & 97 \\
\hline 53 & 29.539682540 & 25.269841270 & 97 \\
\hline 54 & 28.904761905 & 25.825396825 & 97 \\
\hline 55 & 28.444444444 & 26.730158730 & 97 \\
\hline 56 & 27.730158730 & 27.047619048 & 97 \\
\hline
\end{tabular}

Table 2b: Experimental Critical Values Obtained(2)

\section{Critical Values Trend Analyses- Metric SES.}

\subsection{General Procedure Adopted.}

The tabulated data for each CV for metric SES is plotted onto gnuplot and analysed graphically with support from smooth bezier plot. General observations, for each such graph obtained is reported. Several equations of fit are attempted and summary is reported for each SES CV. Ultimately, choice was based firstly on least reduced chi-square value and most plausible extendability produced at node numbers 80, 100 and 120. Finally values of parameters for equation of each SES CV, is noted.

\subsection{Trend Analysis - SES CV1.}

The tendency can safely be assumed to be increasing at a decreasing rate. A staircase feature is also observed, which is probably due to rounding off to nearest unit, and hence is ignored.

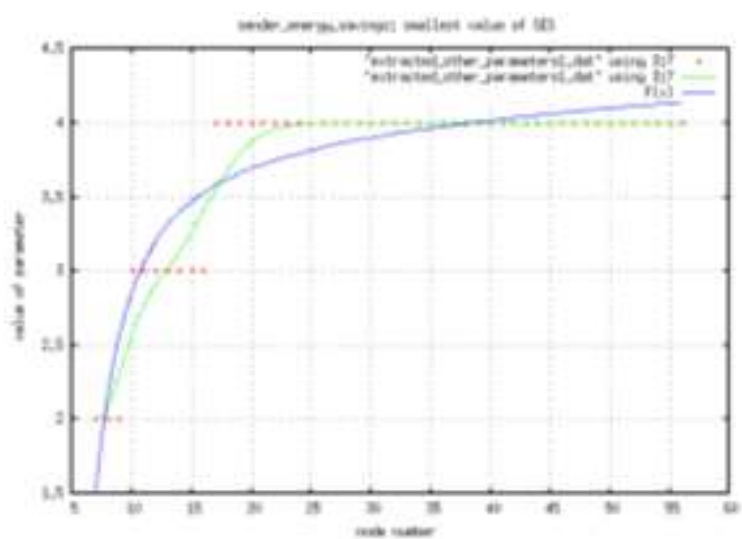

Figure 1: SES Critical Value 1

Below is a summary of potentially applicable equations of trend followed by best choice.

\footnotetext{
1. $F(x)=a * \log ((b * x)+c)+d$ Ch_sq $=0.0708752 \quad \mathrm{~F}(80)=4.435549934591$ $\mathrm{F}(100)=4.555990267756 \quad \mathrm{~F}(120)=4.652965020367$$$
2 \cdot F(x)=a * \log ((b * x)+c)+\left(d \star x^{-1}\right)
$$$$
\text { Ch_sq }=0.06646
$$$$
\mathrm{F}(80)=4.393071020479
$$$$
\mathrm{F}(100)=4.483396104741
$$$$
\mathrm{F}(120)=4.552414979261
$$

$$
\begin{array}{rr}
\text { 3. } F(x)=a * \log ((b * x)+c)+\left(d * x^{-2}\right) \\
\text { Ch_sq }=0.0628543 & F(80)=4.396900642521 \\
F(100)=4.510345750292 & F(120)=4.601967773706 \\
\text { 4. } F(x)=a * \log ((b * x)+c)+\left(d * x^{-3}\right) \\
\text { Ch_sq }=0.0539481 & F(80)=4.263995035112 \\
F(100)=4.339000180150 & F(120)=4.399512409190
\end{array}
$$

\section{Choice of best fit for SES Critical Value 1}

The equation in part 4 above has been selected because of smallest reduced chi-square value obtained and good extendability. The parameters obtained for best fit are:

$a=0.317491, b=9021.77, c=-39034.5, d=-576.052$

\subsection{Trend Analysis - SES CV2.}

The curve obtained mostly depict an increasing tendency at a mildly increasing rate.

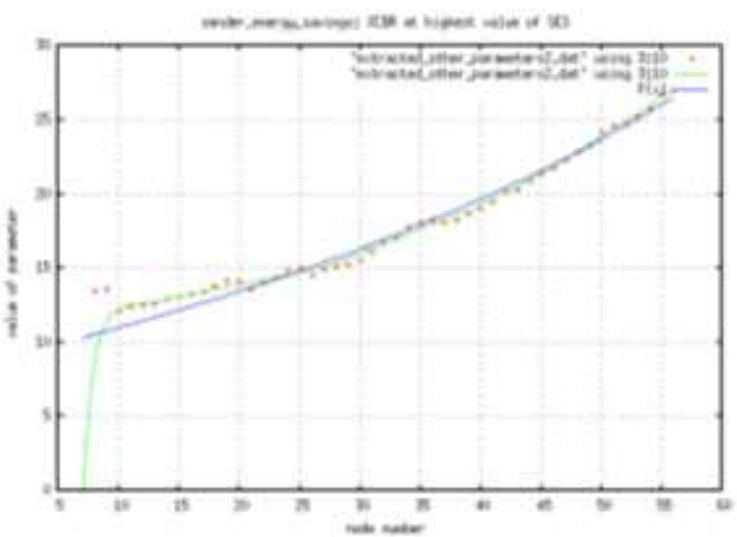

Figure 2: SES Critical Value 2

$$
\begin{aligned}
& \text { 1. } F(x)=a * \exp ((b * x)+c)+d \\
& \text { Ch_sq }=2.97018 \quad \mathrm{~F}(80)=44.142900815 \\
& \mathrm{~F}(100)=67.776891249 \quad \mathrm{~F}(120)=104.900807164 \\
& \text { 2. } F(x)=a \star \exp ((b * x)+c)+(d * x) \\
& \text { Ch_sq }=3.16002 \quad \mathrm{~F}(80)=35.818032106 \\
& \mathrm{~F}(100)=44.378015422 \quad \mathrm{~F}(120)=53.075553631 \\
& \text { 3. } F(x)=a \star \exp ((b * x)+c)+\left(d * x^{0.5}\right) \\
& \text { Ch_sq }=2.97618 \quad \mathrm{~F}(80)=41.350311112 \\
& \mathrm{~F}(100)=60.004098463 \quad \mathrm{~F}(120)=87.250931212 \\
& \text { 4. } F(x)=a{ }^{\star} \exp ((b * x)+c)+\left(d^{\star} x^{0.25}\right) \\
& \text { Ch_sq }=2.73746 \quad \mathrm{~F}(80)=62.650134158 \\
& \mathrm{~F}(100)=159.186188068 \quad \mathrm{~F}(120)=456.827399422
\end{aligned}
$$

\section{Choice of best fit for SES Critical Value 2}

The equation in part 4 above has been selected even if the reduced ch_sq is not smallest, it has good extendability. The parameters obtained for best fit are:

$a=1.894374, b=0.019182, c=1.500255, d=0.218274$ 
Proc. of the Seventh International Conference On Advances in Computing, Electronics and Electrical Technology - CEET 2017. Copyright $(\odot$ Institute of Research Engineers and Doctors. All rights reserved.

ISBN: 978-1-63248-126-9 doi: 10.15224/ 978-1-63248-126-9-19

\subsection{Trend Analysis - SES CV3.}

It is safe to consider the curve depicting an increasing tendency at a decreasing rate, despite the staircase feature observed due to rounding off to nearest unit.

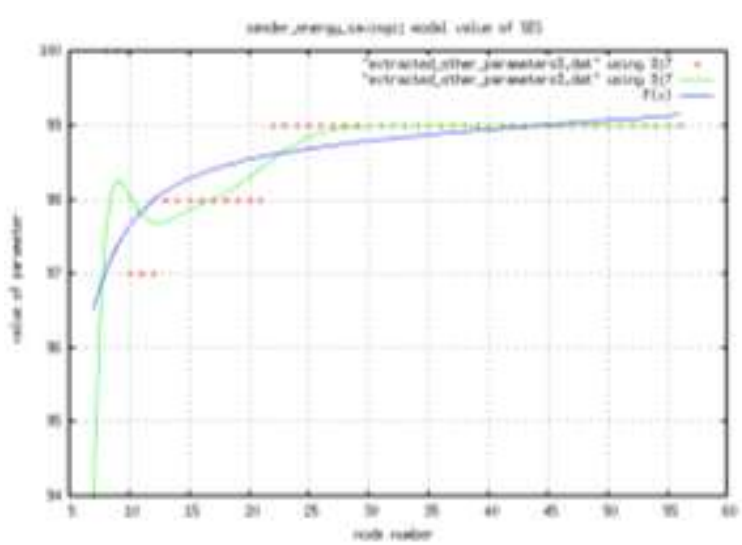

Figure 3: SES Critical Value 3

1. $F(x)=a * \log ((b * x)+c)+d$

Ch_sq $=0.675841 \quad \mathrm{~F}(80)=100.183888715$

$\mathrm{F}(100)=100.828072517 \quad \mathrm{~F}(120)=101.476409732$

2. $F(x)=a * \log ((b * x)+c)+\left(d^{\star} x^{-1}\right)$

$$
\begin{array}{ll}
\text { Ch_sq }=0.581711 & \mathrm{~F}(80)=99.118493094 \\
\mathrm{~F}(100)=99.114621521 & \mathrm{~F}(120)=99.094291978
\end{array}
$$

3. $F(x)=a * \log ((b * x)+c)+\left(d * x^{-2}\right)$

$$
\text { Ch_sq }=0.579284 \quad \mathrm{~F}(80)=99.408436630
$$$$
\mathrm{F}(100)=99.620761846 \quad \mathrm{~F}(120)=99.830808143
$$

4. $F(x)=a * \log ((b * x)+c)+\left(d * x^{-3}\right)$

$$
\begin{array}{ll}
\text { Ch_sq }=0.570972 & \mathrm{~F}(80)=99.564200455 \\
\mathrm{~F}(100)=99.878395218 & \mathrm{~F}(120)=100.193187921
\end{array}
$$

\section{Choice of best fit for SES Critical Value 3}

The equation in part 3 above has been selected even if the reduced ch_sq is not smallest, it has good extendability over larger node numbers. The parameters obtained for best fit are:

$a=1.89437, b=0.0191821, c=1.50026, d=0.218274$

\subsection{Trend Analysis - SES CV4.}

Generally, the curve observed depicts an increasing tendency at a decreasing rate.

$$
\begin{aligned}
& 1 \cdot F(x)=a * \log ((b * x)+c)+d \\
& \text { Ch_sq }=3.00415 \quad \mathrm{~F}(80)=59.549194386 \\
& \mathrm{~F}(100)=66.929705139 \quad \mathrm{~F}(120)=73.208604173 \\
& \text { 2. } F(x)=a \star \log ((b * x)+c)+\left(d * x^{-1}\right) \\
& \text { Ch_sq }=2.50335 \quad \mathrm{~F}(80)=58.502089959 \\
& \mathrm{~F}(100)=65.004763470 \quad \mathrm{~F}(120)=70.405056903 \\
& \text { 3. } F(x)=a \star \log ((b * x)+c)+\left(d * x^{-2}\right) \\
& \text { Ch_sq }=2.4797 \\
& \mathrm{~F}(80)=57.655892326 \\
& \mathrm{~F}(100)=63.700691214 \\
& F(120)=68.683379825
\end{aligned}
$$

$$
\begin{array}{rlrl}
\text { 4. } F(x)=a \star \log & ((b * x)+c)+\left(d * x^{-3}\right) \\
\text { Ch_sq } & =2.52975 & & F(80)=57.662186814 \\
F(100) & =63.780602046 & & F(120)=68.840599146
\end{array}
$$

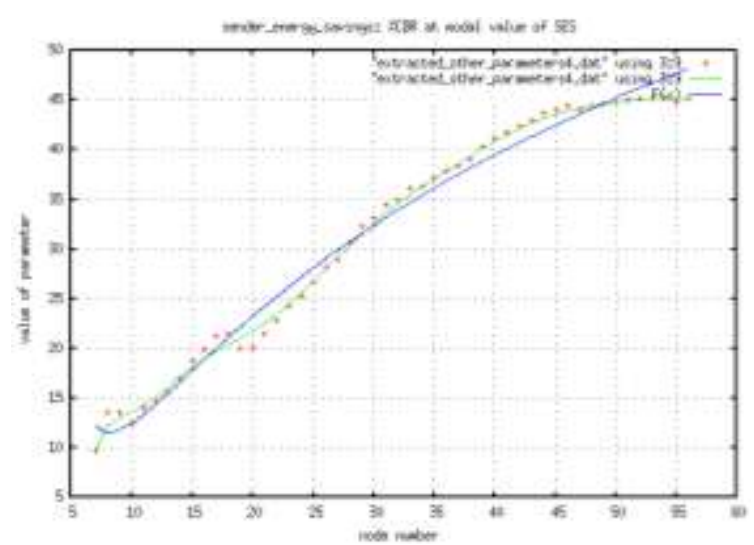

Figure 4: SES Critical Value 4

\section{Choice of best fit for SES Critical Value 4}

The equation in part 3 above has been selected because of smallest ch_sq and good extendability over larger node numbers. The parameters obtained for best fit are:

$\mathrm{a}=28.2863, \mathrm{~b}=0.0917501, \mathrm{c}=0.309486, \mathrm{~d}=662.803$

\subsection{Trend Analysis - SES CV5.}

Three different trends are observed here with decreasing tendency at a decreasing rate, for the following ranges:

i. $\quad$ For node number 7-12.

ii. For node number 13-21.

iii. $\quad$ For node number 22-56.

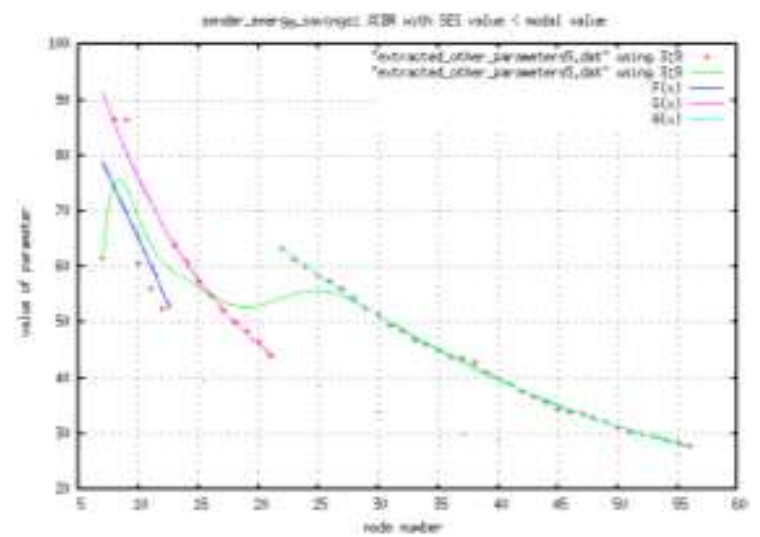

Figure 5: SES Critical Value 5

The applicable equations have been:

$F(x)=\left\{\begin{array}{lr}d^{*} x+f & \text { for node number 7-12 } \\ a^{*} \exp \left(\left(b^{*} x\right)+c\right)+g & \text { for node number 13-21 } \\ i^{*} \exp \left(\left(j^{*} x\right)+k\right)+1 & \text { for node number 22-56 }\end{array}\right.$

For node number 7-12: $\quad$ Ch_sq $=194.529, \quad \mathrm{~d}=$ -

$4.64648, \mathrm{f}=111.448$ 
Proc. of the Seventh International Conference On Advances in Computing, Electronics and Electrical Technology - CEET 2017. Copyright (C) Institute of Research Engineers and Doctors. All rights reserved.

ISBN: 978-1-63248-126-9 doi: 10.15224/ 978-1-63248-126-9-19

For node number 13-21: 2 equations were attempted here. The second one is better.

$$
\begin{aligned}
& \text { 1. } F(x)=d * x+f \\
& \text { Ch_sq }=0.594302, d=-2.44392, \\
& f=94.6859 \\
& \text { 2. } F(x)=a * \exp ((b * x)+c)+g \\
& \text { Ch_sq }=0.114024, a=1.51212, \\
& b=-0.0897801, c=4.40079, d \\
& =25.62324
\end{aligned}
$$

For node number 22-56

$$
\begin{array}{lrl}
F(x)=i * \exp & ((j * x)+k)+1 \\
\text { Ch_sq }=0.161405 & F(80)=17.714460388 \\
F(100)=13.729327669 & F(120)=11.632574350
\end{array}
$$

Parameters of fit are:

$\mathrm{i}=2.13962, \mathrm{j}=-0.032109, \mathrm{k}=3.93751, \mathrm{l}=9.30445$.

\subsection{Trend Analysis - SES CV6.}

Here also, three different trends are observed with decreasing tendency at a decreasing rate :
i. $\quad$ For node number 7-12.
ii. For node number 13-21.
iii. For node number 22-56.

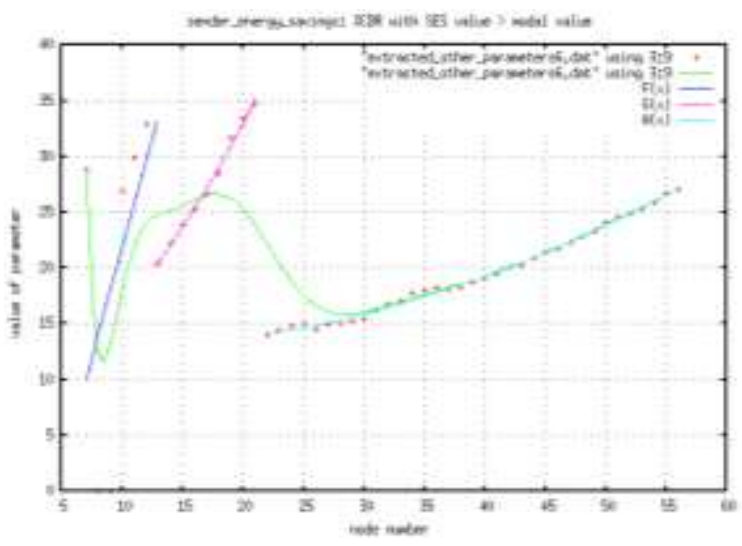

Figure 6: SES Critical Value 6

$F(x)=\left\{\begin{array}{lr}d^{*} x+f & \text { for node number 7-12 } \\ a^{*} \exp \left(\left(b^{*} x\right)+c\right)+g & \text { for node number 13-21 } \\ i^{*} \exp \left(\left(j^{*} x\right)+k\right)+\left(I^{*} x^{-3}\right) & \text { for node number 22-56 }\end{array}\right.$

For node number 7-12

$$
\begin{aligned}
& F(x)=d^{*} x+f \\
& C h \_s q=229.66, \quad d=3.91086, f=-17.4275
\end{aligned}
$$

For node number 13-21

$$
\mathrm{F}(\mathrm{x})=\mathrm{a} * \exp ((\mathrm{b} * \mathrm{x})+\mathrm{c})+\mathrm{g}
$$

Ch_sq $=0.304171, \mathrm{a}=0.262796, \mathrm{~b}=0.0488352$, $\mathrm{c}=4.12616, \mathrm{~d}=-10.2271$
For node number 22-56: Here several equations were tried before choosing the fourth one for best extendability even if the ch_sq is not least.

$$
\begin{aligned}
& 1 \cdot F(x)=i * \exp ((j \star x)+k)+1 \\
& \text { Ch_sq }=0.0838558 \quad \mathrm{~F}(80)=49.488875228 \\
& \mathrm{~F}(100)=85.676839485 \quad \mathrm{~F}(120)=152.493205884 \\
& 2 \cdot F(x)=i * \exp ((j * x)+k)+\left(I * x^{-1}\right) \\
& \text { Ch_sq }=0.0817818 \quad \mathrm{~F}(80)=46.759586417 \\
& \mathrm{~F}(100)=74.282022556 \quad \mathrm{~F}(120)=118.409249666 \\
& \text { 3. } F(x)=i \star \exp ((j * x)+k)+\left(I * x^{-2}\right) \\
& \text { Ch_sq }=0.0817352 \quad \mathrm{~F}(80)=49.950426799 \\
& \mathrm{~F}(100)=71.577935658 \quad \mathrm{~F}(120)=111.598261113 \\
& 4 \cdot F(x)=i \star \exp ((j * x)+k)+\left(I * x^{-3}\right) \\
& \text { Ch_sq }=0.0821822 \quad \mathrm{~F}(80)=45.452166973 \\
& \mathrm{~F}(100)=70.074572645 \quad \mathrm{~F}(120)=108.063678764
\end{aligned}
$$

The parameters of fit are: $\quad \mathrm{i}=0.1331739, \mathrm{j}=0.021$ $6639, \mathrm{k}=4.0990798, \mathrm{l}=13193.933634$

\subsection{Trend Analysis - SES CV7.}

Here the curve obtained depicts an increasing trend at a decreasing rate. Some staircase feature is also noticed but is not of big amplitude and hence ignored.

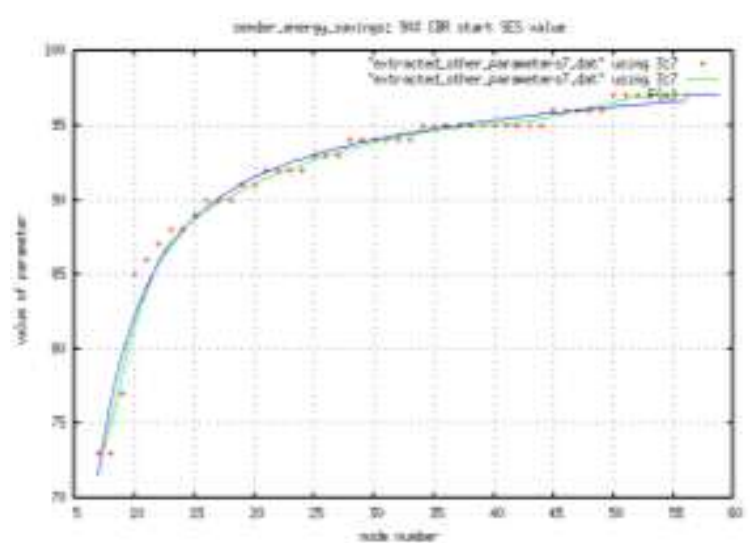

Figure 7: SES Critical Value 7

1. $F(x)=a * \log ((b * x)+c)+d$

$$
\text { Ch_sq }=1.60047 \quad \mathrm{~F}(80)=99.708689563
$$

$\mathrm{F}(100)=100.998687149 \quad \mathrm{~F}(120)=102.037356703$

2. $F(x)=a \star \log ((b * x)+c)+\left(d * x^{-1}\right)$

$$
\text { Ch_sq }=1.75685 \quad \mathrm{~F}(80)=98.883092380
$$$$
\mathrm{F}(100)=99.707846237 \quad \mathrm{~F}(120)=100.327115790
$$

3. $F(x)=a * \log ((b * x)+c)+\left(d * x^{-2}\right)$

$$
\text { Ch_sq }=0.862664 \quad \mathrm{~F}(80)=98.277283184
$$$$
\mathrm{F}(100)=99.230925379 \quad \mathrm{~F}(120)=100.025048012
$$

4. $F(x)=a * \log ((b * x)+c)+\left(d * x^{-2.5}\right)$

$$
\begin{array}{ll}
\text { Ch_sq }=0.865156 & \mathrm{~F}(80)=98.653079912 \\
\mathrm{~F}(100)=99.737070180 & \mathrm{~F}(120)=100.630922354
\end{array}
$$


Proc. of the Seventh International Conference On Advances in Computing, Electronics and Electrical Technology - CEET 2017. Copyright (C) Institute of Research Engineers and Doctors. All rights reserved.

ISBN: 978-1-63248-126-9 doi: 10.15224/ 978-1-63248-126-9-19

$$
\begin{array}{rlrl}
\text { 5. } F(x)=a * \log & ((b * x)+c)+\left(d * x^{-1.75}\right) \\
\text { Ch_sq } & =0.89546 & F(80)=97.991679069 \\
F(100)=98.811670426 & F(120)=99.492831454
\end{array}
$$

Relays, CEET 2014

[5] M. Kaleem GALAMALI, Assoc. Prof Nawaz MOHAMUDALLY, Mathematical modeling of need of exact number of relays to ensure seamless mobility in mobile computing, CEET 2014

[6] M. Kaleem GALAMALI, Assoc. Prof Nawaz MOHAMUDALLY, Modelling of need for multiple relays for ensuring seamless mobility, CEET 2014

\section{Choice of best fit for SES Critical Value 7}

The equation in part 4 above has been selected even if the reduced ch_sq is not smallest, it has good extendability over larger node numbers. The parameters obtained for best fit are:

$$
\begin{aligned}
& a=4.71031, b=9.53817\left(e^{+06}\right), c=3.95952\left(e^{+08}\right) \\
& d=-677.022
\end{aligned}
$$

\section{Conclusion.}

This piece of research was aimed at and has achieved the identification of some critical values concerned for metric SES and their corresponding trends over varying node densities in a MANET topography of $300 \times 300$ $\mathrm{m}^{2}$. The models put forward will help to study MANETs for MAUC environment from a software engineering perspective. The models put forward in this paper, are mathematical in nature and can be used by designers towards producing more realistic simulation scenarios for testing newly developed protocols and middleware for ubicomp. The experiment was carried out in NS-2 over Linux. The plottings and fitting attempts were done in gnuplot. Best fit was evaluated from reduced chi-square values and best extendability of equations obtained.

Assumptions stated in previous papers [14, 30] hold here also. Gnuplot is also assumed as appropriate. The intrinsic constructs of gnuplot is not questioned here.

This work is a follow-up of previous papers [1-13, 14, $30]$ and remain open for further refinements. One such further work identified is formulating a method of predictability for metric SES and its trend.

\section{References}

[1] M. Kaleem GALAMALI, Assoc. Prof Nawaz MOHAMUDALLY, Towards Dependable Pervasive Systems-A Position and Vision Paper, CEET 2014

[2] M. Kaleem GALAMALI, Assoc. Prof Nawaz MOHAMUDALLY, Model of Energy Savings achievable with Location-aware Node-to-Node Transmission in UbiComp , CEET 2014

[3] M. Kaleem GALAMALI, Assoc. Prof Nawaz MOHAMUDALLY, Model of Energy Savings achievable with Location-aware Node-to-Node Transmission in UbiComp Using Location Refresh Intervals, CEET 2014

[4] M. Kaleem GALAMALI, Assoc. Prof Nawaz MOHAMUDALLY, Model of Energy Savings achievable with Location-aware Transmission in UbiComp Using
[7] M. Kaleem GALAMALI, Assoc. Prof Nawaz MOHAMUDALLY, Investigation of prominence of placements of relays in a ubicomp topography,

[8] M. Kaleem GALAMALI, Assoc. Prof Nawaz MOHAMUDALLY, Model of energy savings achievable with location-aware transmission in ubicomp using optimised number of relays.

[9] M. Kaleem GALAMALI, Assoc. Prof Nawaz MOHAMUDALLY, Investigation of Prominence of Placements of Optimised Number of Relays in a Ubicomp Topography using Location-Aware Transmission, CEET 2015.

[10] M. Kaleem GALAMALI, Assoc. Prof Nawaz MOHAMUDALLY, Extending Node Battery Availability in Ubicomp with Location-Aware Transmission, CEET 2015.

[11] M. Kaleem GALAMALI, Assoc. Prof Nawaz MOHAMUDALLY, Extending Node Battery Availability in Ubicomp with Location-Aware Transmission using Location Refresh Intervals, CEET 2015.

[12] M. Kaleem GALAMALI, Assoc. Prof Nawaz MOHAMUDALLY, Extending Node Battery Availability in Ubicomp with Location-Aware Transmission using Uniformly Placed Relays, CEET 2015.

[13] M. Kaleem GALAMALI, Assoc. Prof Nawaz MOHAMUDALLY, Extending Node Battery Availability in Ubicomp with Location-Aware Transmission Using Optimally Placed Relays, CEET 2015.

[14] M. Kaleem GALAMALI, Assoc. Prof Nawaz MOHAMUDALLY, Model of Sender Node Energy Savings Achievable with Location-Aware MANET Transmission in Ubicomp. ACCN 2016

[15] M. Kaleem GALAMALI, Assoc. Prof Nawaz MOHAMUDALLY, Model of Overall Node Energy Savings Achievable with Location-Aware MANET Transmission in Ubicomp. ACCN 2016

[16] M. Kaleem GALAMALI, Assoc. Prof Nawaz MOHAMUDALLY, Model of Sender Node Extra Energy Savings Achievable in MANET Against Direct Node-toNode Transmission Using Location-Aware Transmission in Ubicomp. ACCN 2016

[17] M. Kaleem GALAMALI, Assoc. Prof Nawaz MOHAMUDALLY, Model of Overall Node Extra Energy Savings Achievable in MANET against Direct Node-toNode Transmission Using Location-Aware Transmission in Ubicomp. ACCN 2016

[18] M. Kaleem GALAMALI, Assoc. Prof Nawaz MOHAMUDALLY, Model of Energy Consumption Ratio Achievable in MANET Using Location-Aware Transmission in Ubicomp. ACCN 2016

[19] M. Kaleem GALAMALI, Assoc. Prof Nawaz MOHAMUDALLY, Model of Minimum Energy Consumption Ratio Achievable in MANET Using LocationAware Transmission in Ubicomp. ACCN 2016

[20] M. Kaleem GALAMALI, Assoc. Prof Nawaz MOHAMUDALLY, Model of Maximum Energy Consumption Ratio Achievable in MANET Using LocationAware Transmission in Ubicomp. ACCN 2016

[21] M. Kaleem GALAMALI, Assoc. Prof Nawaz MOHAMUDALLY, Model of Overall Energy Consumption Fairness Ratio Achievable in MANET Using LocationAware Transmission in Ubicomp. ACCN 2016

[22] M. Kaleem GALAMALI, Assoc. Prof Nawaz MOHAMUDALLY, Model of Overall Energy Consumption Fairness Proportion Achievable in MANET Using LocationAware Transmission for Ubicomp, CEET 2016

[23] M. Kaleem GALAMALI, Assoc. Prof Nawaz MOHAMUDALLY, Model of Minimum Fairness Proportion Achievable in MANET Using Location-Aware Transmission for Ubicomp, CEET 2016 
Proc. of the Seventh International Conference On Advances in Computing, Electronics and Electrical Technology - CEET 2017. Copyright $(\odot$ Institute of Research Engineers and Doctors. All rights reserved.

ISBN: 978-1-63248-126-9 doi: 10.15224/ 978-1-63248-126-9-19

[24] M. Kaleem GALAMALI, Assoc. Prof Nawaz MOHAMUDALLY, Model of Maximum Fairness Proportion Achievable in MANET Using Location-Aware Transmission for Ubicomp, CEET 2016

[25] M. Kaleem GALAMALI, Assoc. Prof Nawaz MOHAMUDALLY, Model of Sender Fairness Proportion Achievable in MANET Using Location-Aware Transmission for Ubicomp, CEET 2016

[26] M. Kaleem GALAMALI, Assoc. Prof Nawaz MOHAMUDALLY, Model of Distance Travelled by packets in MANETs using Location-Aware Transmission for Ubicomp, CEET 2016

[27] M. Kaleem GALAMALI, Assoc. Prof Nawaz MOHAMUDALLY, Model of Maximum CBR Distance Travelled by packets in MANETs using Location-Aware Transmission for Ubicomp, CEET 2016

[28] M. Kaleem GALAMALI, Assoc. Prof Nawaz MOHAMUDALLY, Model of Minimum CBR Distance Travelled by packets in MANETs using Location-Aware Transmission for Ubicomp, CEET 2016

[29] M. Kaleem GALAMALI, Assoc. Prof Nawaz MOHAMUDALLY, Model of Range CBR Distance Experienced by Transmissions in MANETs using LocationAware Transmission for Ubicomp, CEET 2016

[30] M. Kaleem GALAMALI, Assoc. Prof Nawaz MOHAMUDALLY, Trend Analyses of Parameters of Equations for Sender Node Energy Savings Achievable in ubicomp MANETs using Location-Aware Transmission, ACCN 2017.

[31] M. Kaleem GALAMALI, Assoc. Prof Nawaz MOHAMUDALLY, Trend Analyses of Parameters of Equations for Overall Node Energy Savings Achievable in ubicomp MANETs using Location-Aware Transmission, ACCN 2017.

[32] M. Kaleem GALAMALI, Assoc. Prof Nawaz MOHAMUDALLY, Trend Analyses of Parameters of Equations for Sender Node Extra Energy Savings Achievable in MANET against Direct Node-to-Node Location-Aware Transmission, ACCN 2017.

[33] M. Kaleem GALAMALI, Assoc. Prof Nawaz MOHAMUDALLY, Trend Analyses of Parameters of Equations for Overall Nodes Extra Energy Savings Achievable in MANET against Direct Node-to-Node Location-Aware Transmission, ACCN 2017.

[34] M. Kaleem GALAMALI, Assoc. Prof Nawaz MOHAMUDALLY, Trend Analyses of Parameters of Equations for Energy Consumption Ratio Achievable in Ubicomp MANET Using Location-Aware Transmission, ACCN 2017.

[35] M. Kaleem GALAMALI, Assoc. Prof Nawaz MOHAMUDALLY, Trend Analyses of Parameters of Equations for Minimum Energy Consumption Ratio Achievable in Ubicomp MANETs Using Location-Aware Transmission, ACCN 2017.

[36] M. Kaleem GALAMALI, Assoc. Prof Nawaz MOHAMUDALLY, Trend Analyses of Parameters of Equations for Maximum Energy Consumption Ratio Achievable in Ubicomp MANETs Using Location-Aware Transmission, ACCN 2017.

[37] M. Kaleem GALAMALI, Assoc. Prof Nawaz MOHAMUDALLY, Trend Analyses of Parameters of Equations for Overall Fairness Ratio Achievable in Ubicomp MANETs Using Location-Aware Transmission, ACCN 2017.

[38] M. Kaleem GALAMALI, Assoc. Prof Nawaz MOHAMUDALLY, Trend Analyses of Parameters of Equations for Energy Consumption Fairness Proportion Achievable in Ubicomp MANETs Using Location-Aware Transmission, CEET 2017

[39] M. Kaleem GALAMALI, Assoc. Prof Nawaz MOHAMUDALLY, Trend Analyses of Parameters of Equations for Minimum Fairness Proportion Achievable in Ubicomp MANETs Using Location-Aware Transmission, CEET 2017

[40] M. Kaleem GALAMALI, Assoc. Prof Nawaz MOHAMUDALLY, Trend Analyses of Parameters of Equations for Maximum Fairness Proportion Achievable in Ubicomp MANETs Using Location-Aware Transmission, CEET 2017
[41] M. Kaleem GALAMALI, Assoc. Prof Nawaz MOHAMUDALLY, Trend Analyses of Parameters of Equations for Sender Fairness Proportion Achievable in Ubicomp MANETs Using Location-Aware Transmission, CEET 2017

[42] M. Kaleem GALAMALI, Assoc. Prof Nawaz MOHAMUDALLY, Trend Analyses of Parameters of Equations for Packets Per Distance Achievable in Ubicomp MANETs Using Location-Aware Transmission, CEET 2017

[43] M. Kaleem GALAMALI, Assoc. Prof Nawaz MOHAMUDALLY, Trend Analyses of Parameters of Equations for Maximum CBR Distance Achievable in Ubicomp MANETs Using Location-Aware Transmission, CEET 2017

[44] M. Kaleem GALAMALI, Assoc. Prof Nawaz MOHAMUDALLY, Trend Analyses of Parameters of Equations for Minimum CBR Distance Achievable in Ubicomp MANETs Using Location-Aware Transmission, CEET 2017

[45] M. Kaleem GALAMALI, Assoc. Prof Nawaz MOHAMUDALLY, Trend Analyses of Parameters of Equations for Range CBR Distance Achievable in Ubicomp MANETs Using Location-Aware Transmission, CEET 2017

[46] Markus Bylund and Zary Segall, Towards seamless mobility with personal servers, 2004.

[47] Masugi Inoue, Mikio Hasegawa, Nobuo Ryoki and Hiroyuki Morikawa, Context-Based Seamless Network and Application Control, 2004

[48] Xiang Song, Umakishore Ramachandran, MobiGo: A Middleware for Seamless Mobility, College of Computing Georgia Institute of Technology, Atlanta, GA, USA, August 2007

[49] Budzisz, Ferrús, R., Brunstrom A., Grinnemo, K, Fracchia, R., Galante, G., and Casadevall, F. Towards transport-layer mobility: Evolution of SCTP multihoming, March 2008

[50] Paul Dourish \& Genevieve Bell, Divining a digital future, 2011

[51] Xiang Song, Seamless Mobility In Ubiquitous Computing Environments, PhD Thesis, Georgia Institute of Technology, August 2008

[52] Kevin O Mahony, Jian Liang, Kieran Delaney, User-Centric Personalization and Autonomous Reconfiguration Across Ubiquitous Computing Environments, NIMBUS Centre Cork Institute of Technology, Cork, Ireland, UBICOMM 2012

[53] Pablo Vidales, Seamless mobility in $4 \mathrm{G}$ systems, Technical Report, University of Cambridge, Computer Laboratory, Number 656, November 2005

[54] João Pedro Sousa and David Garlan, Aura: An Architectural Framework for User Mobility in Ubiquitous Computing Environments, School of Computer Science, Carnegie Mellon University, USA, August 2002

[55] Dennis Lupiana, Ciaran O'Driscoll, Fredrick Mtenzi, Defining Smart Space in the Context of Ubiquitous Computing, Dublin Institute of Technology, Ireland, Special Issue on ICIT 2009 Conference - Web and Agent Systems, 2009

[56] N.S.V.Shet1, Prof.K.Chandrasekaran2 and Prof. K.C.Shet3, WAP Based Seamless Roaming In Urban Environment with Wise Handoff Technique, International Journal of UbiComp (IJU), Vol.1, No.4, October 2010

[57] Yipeng Yu Dan He Weidong Hua Shijian Li Yu Qi Yueming Wang Gang Pan, FlyingBuddy2: A Braincontrolled Assistant for the Handicapped, Zhejiang University, UbiComp'12, September 5-8, 2012.

[58] Jing Su, James Scott, Pan Hui, Jon Crowcroft, Eyal de Lara Christophe Diot, Ashvin Goel, Meng How Lim, and Eben Upton, Haggle: Seamless Networking for Mobile Applications, 2007

[59] Rui Han, Moustafa M. Ghanem, Li Guo, Yike Guo*, Michelle Osmond, Enabling cost-aware and adaptive elasticity of multi-tier cloud applications, Future Generation Computer Systems, 2012

[60] Byrav Ramamurthy, K. K. Ramakrishnan, Rakesh K. Sinha, Cost and Reliability Considerations in Designing the NextGeneration IP over WDM Backbone Networks, 2012.

[61] Bhavish Aggarwal, Aditya Akella, Ashok Anand, Athula Balachandran, Pushkar Chitnis, Chitra Muthukrishnan, Ram Ramjee and George Varghese, EndRE: An End-System 
Proc. of the Seventh International Conference On Advances in Computing, Electronics and Electrical Technology - CEET 2017. Copyright $(\odot$ Institute of Research Engineers and Doctors. All rights reserved.

ISBN: 978-1-63248-126-9 doi: 10.15224/ 978-1-63248-126-9-19

Redundancy Elimination Service for Enterprises, NSDI 2010, San Jose, CA

[62] Ashok Anand, Vyas Sekar and Aditya Akella, SmartRE: An Architecture for Coordinated Network-wide Redundancy Elimination, SIGCOMM 2009, Barcelona, Spain

[63] John Breeden II, "Smart-phone battery life could double without better batteries", Nov 14, 2012

[64] Andy Boxall, "When will your phone battery last as long as your kindle", December 5, 2012.

[65] Imielinski, T. and Navas, J.C. (1999). GPS-based geographic addressing, routing, and resource discovery. Comms. ACM, Vol. 42, No. 4, pp. 86-92.

[66] Hightower, J. and Borriello, G. (2001). Location Systems for Ubiquitous Computing. IEEE Computer, Vol. 34, No. 8, August, pp. 57-66.

[67] Harter, A., Hopper, A., Steggles, P., Ward, A. and Webster, P. (2002). The Anatomy of a Context-Aware Application. Wireless Networks, Vol. 8, No. 2-3, Mar-May, pp. 187-197.

[68] Hightower, J., Brumitt, B. and Borriello, G. (2002). The Location Stack: A Layered Model for Location in Ubiquitous Computing. Proceedings of the 4th IEEE Workshop on Mobile Computing Systems \& Applications (WMCSA 2002), Callicoon, NY, USA, June, pp. 22-28.

[69] Graumann, D., Lara, W., Hightower, J. and Borriello, G. (2003). Real-world implementation of the Location Stack: The Universal Location Framework. Proceedings of the 5th IEEE Workshop on Mobile Computing Systems \& Applications (WMCSA 2003), Monterey, CA, USA, October, pp. 122-128.

[70] Ko, Y., \& Vaidya, N. H. (2000). Location-aided routing (LAR) in mobile ad hoc networks. Wireless Networks, 6(4), 307-321.

[71] Liao, W.-H., Tseng, Y.-C., \& Sheu, J.-P. (2001). GRID: a fully location-aware routing protocol for mobile ad hoc networks. Telecommunication Systems, 18(1), 37-60.

[72] Kuhn, F., Wattenhofer, R., Zhang, Y., \& Zollinger, A. (2003). Geometric ad-hoc routing: of theory and practice. In Proceedings of the ACM (PODC'03) (pp. 63-72).

[73] Jiang, X., \& Camp, T. (2002). Review of geocasting protocols for a mobile ad hoc network. In Proceedings of the Grace Hopper Celebration (GHC).

[74] Ko, Y. \& Vaidya, N. H. (1999). Geocasting in mobile ad hoc networks: location-based multicast algorithms. In Proceedings of the IEEE (WMCSA'99) (pp. 101).

[75] Mauve, M., Fuler, H., Widmer, J., \& Lang, T. (2003). Position-based multicast routing for mobile ad-hoc networks (Technical Report TR-03-004). Department of Computer Science, University of Mannheim.

[76] Xu, Y., Heidemann, J., \& Estrin, D. (2001). Geographyinformed energy conservation for adhoc routing. In Proceedings of the ACM/IEEE (MOBICOM'01) (pp. 70-84).

[77] Hu, Y.-C., Perrig, A., \& Johnson, D. (2003). Packet leashes: a defense against wormhole attacks in wireless ad hoc networks. In Proceedings of the INFOCOM' 03 (pp. 19761986).

[78] Patwari, N., Hero III, A. O., Perkins, M., Correal, N. S., \& O'Dea, R. J. (2003). Relative location estimation in wireless sensor networks. IEEE Transactions on Signal Processing, 51(8), 2137-2148.

[79] Baldauf, M., Dustdar, S., \& Rosenberg, F. (2007). A Survey on Context Aware Systems. International Journal of Ad Hoc and Ubiquitous Computing, Inderscience Publishers. forthcoming. Pre-print from: http://www.vitalab.tuwien.ac.at/ florian/papers/ijahuc2007.pdf

[80] Hong, D., Chiu, D.K.W., \& Shen, V.Y. (2005). Requirements elicitation for the design of context-aware applications in a ubiquitous environment. In Proceedings of ICEC'05 (pp. 590-596).

[81] Neeraj Tantubay, Dinesh Ratan Gautam and Mukesh Kumar
Dhariwal, A Review of Power Conservation in Wireless Mobile Ad hoc Network (MANET)", International Journal of computer Science Issues, Vol 8, Issue 4, No 1, July 2011.

[82] Wenrui Zhao, Mostafa Ammar and Ellen Zegura, "A Message Ferrying Approach for Data Delivery in Sparse Mobile Ad Hoc Networks", MobiHoc'04, May 24-26, 2004, Roppongi, Japan.

[83] Sgroi et al., "Designing Wireless Protocols: Methodology and Applications, February 2000.

[84] Gyula et al., "Simulation-based optimization of communication protocols for large-scale wireless sensor networks", 10 October 2002

[85] Rao and Sharma, "Cross Layer Protocols For Multimedia Transmission in Wireless Networks", June 2012

[86] Herms et al, "Realism in Design and Evaluation of Wireless Routing Protocols", 2007.

About Author (s):

Associate Professor Nawaz Mohamudally works at University of Technology, Mauritius (UTM) and has undertaken supervision of $\mathrm{MPhil} / \mathrm{PhD}$ Students for many years.

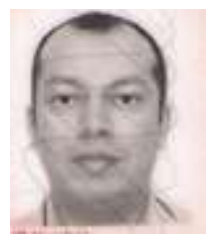

M. Kaleem Galamali is a part-time student (achieved M Phil Transfer on 28.10.2014, currently $\mathrm{PhD}$ student) at UTM under supervision of A.P. Nawaz Mohamudally. 